\title{
Lichenoid Drug Eruption
}

National Cancer Institute

\section{Source}

National Cancer Institute. Lichenoid Drug Eruption. NCI Thesaurus. Code C34780.

A red or violaceous flat-topped, papular eruption that is induced by exposure to a variety

of medications or environmental agents. 